\title{
Tekniikka ja traditio
}

\section{Havaintoja tuotantotekniikan omaksumisen kehityksestä}

\begin{abstract}
Huttunen, Pertti. 1987. Tekniikka ja traditio. Havaintoja tuotantojärjestelmän omaksumisen kehityksestä. Aikuiskasvatus 7, 4. 140-144. - Ihmisen pystykäynti liittyy primaarisesti jälkeläisistä huolehtimisen tarpeisiin. Ilmeisesti työ ja työvälineitten käyttö tulivat mahdollisiksi vasta sitten, kun pystykäyntiä seurannut sosiaalistumiskehitys oli jatkunut noin miljoona vuotta. Mitä pitemmälle ihmisen sosiaalistumiskehitys eteni, sitä tärkeämmiksi tulivat erilaiset opitut sosiaalisen käyttäytymisen muodot. Keskeinen tekijä tämän muutosprosessin myöhäisvaiheessa oli nimenomaisesti työ. Primitiivisissä yhteisöissä ei työnjakoa juuri ollut. Yhteisöjen tuotannollisen kokemuksen, työn, tuotantovoiman ja tarpeiden lisääntyessä kehittyi niiden sisäinen työnjako ja myöhemmin klaanijärjestelmä, jonka puitteissa työhön ja tuotantoon liittyvä traditio jakaantui eri klaanien kesken. Antiikin kaupunkijärjestelmän syntyessä särkyi sukulaisuuteen perustunut ammattitraditio ja työorganisatio. Antiikin orjajärjestelmän vallitessa lisääntyvä luontoa ja yhteiskuntaa koskeva tieto ja tekninen traditio joutuivat erilleen. Keskiajan kaupunkien käsityöläisillä sen sijaan oli historiallis-yhteiskunnallisen kehityksen seurauksena käytössään tuotannollinen ja sosiaalinen organisaatio, ammattikuntalaitos, jonka sisällä tekninen traditio ja laajempi tietopohja integroituivat. Ja lisääntyvästä vaihdon tarpeesta syntynyt työn tuotantovoimien kasvu ennen pitkää ylitti ammattikuntajärjestelmän rajat. Käsityötraditio muuttui tiedepohjaiseksi koulutustraditioksi.
\end{abstract}

\section{Biologisesta evoluutiosta kulttuurievoluutioon}

On perusteltua puhua erikseen ihmisen biologisesta evoluutiosta eli lajikehityksestä ja kulttuurievoluutiosta eli historiasta, mutta on väärin kuvitella, että jossain kaukaisessa menneisyydessä on ollut ratkaiseva käännekohta, jossa ihmisen biologinen evoluutio loppui ja kulttuurikehitys alkoi. Tosiasiassa nämä kaksi muutosprosessia ovat nivoutuneet erottamattomasti toisiinsa, oikeastaan ne ovat saman kokonaiskehityksen kaksi toisiinsa jatkuvasti vaikuttavaa juonnetta, jossa kulttuurievoluutio nopeampana ja näkyvämpänä on jättänyt biologiset muutokset varjoonsa. Jos ajatellaan ihmiselle tyypillistä älyllistä kapasiteettia, sen kehitys sai alkunsa jo kymmeniä miljoonia vuosia sitten, kun savannilta puihin siirtyneitten kädellisten esi-isien silmät alkoivat vähitellen siirtyä kallon sivuilta sen etuosaan, jolloin etäisyyksien arviointikyky parani ja aivot saivat kasvulleen lisätilaa.
Ihmisen sosiaalistumiskehityksen lähtökohtana on se paradoksaalinen tosiasia, että aivokapasiteetin kehittyminen oli vienyt monet ihmisapinat lähelle lajikuolemaa. Kymmeniä miljoonia vuosia katkeamattomana jatkunut kädellisten aivotilan ja aivokapasiteetin kasvu oli vääjäämättömästi johtanut kädellisten pitkään lapsuuteen, sillä emon oli huolehdittava fyysisesti heikoista jälkeläisistään, jotka kykenivät tulemaan toimeen vasta pitkällisen kasvamis- ja oppimisprosessin eli lapsuuden jälkeen. Kun korkeitten kädellisten lapsuus kestää vuosia eikä äiti voi saada uutta jälkeläistä ennen kuin entinen on varttunut täysi-ikäiseksi, naaraitten synnytykset kävivät väistämättä harvalukuisiksi. Esimerkiksi orangutangi-naaras voi pariutua vain kerran viidessä tai kuudessa vuodessa, ja lauman tai jopa lajin olemassaolo saattaa helposti vaarantua jo muutamien synnytysten epäonnistumisen vuoksi. Erityisen lähelle lajikuoleman vaara tulee silloin, kun poikkeuksellisen suuri joukko lauman ja lajin jäseniä tuhoutuu niiden elinympä- 
ristön muutosten vuoksi. Tämä on tilanne juuri nyt: Tämän päivän maailmassa useimmat ihmisenmuotoiset apinat ovat vakavasti uhanalaisia lajeja, mikä paljolta johtuu niiden lähisukulaisen, ihmisen aiheuttamista ympäristönmuutoksista, joihin hitaasti lisääntyvät apinat eivät ole kyenneet mukautumaan. Miten tämä on mahdollista? Miten on mahdollista, että niin lähisukulaiset eläimet kuin ihminen ja ihmisenmuotoiset apinat ovat niin erilaisessa asemassa lajin säilymistä ajatellen, miksi toinen on menestyksellisesti lisääntynyt ja on tällä hetkellä sananmukaisesti täyttämässä maan ja toiset ovat kuolemassa sukupuuttoon?

Vastausta edellä esitettyyn kysymykseen on haettava 3-4 miljoonan vuoden takaa, jolloin homo sapiensin esi-isien evoluutioura erosi korkeampien apinoiden kehityslinjasta. Näiden kahden evoluutiokehityksen välillä on paljon eroavuuksia, mutta suurin ja kaikkia muita parhaiten selittävä ero apinoitten ja ihmisen esi-isien, hominidien, välillä oli suvunjatkamisstrategiassa. Hominideilla aivotilan ja älyllisen potentiaalin kasvu oli nopeampaa kuin apinoilla, ja kun lisääntyvä älyllinen potentiaali vaati yhä pitempää lapsuutta, olisivat naaraitten synnytykset käyneet todella harvalukuisiksi, ellei pystykäynti olisi kehittynyt suunnilleen samantahtisesti aivotilavuuden kasvun kanssa ja vapauttanut eturaajoja ravinnon kokoamiseen ja jälkeläisten kuljettamiseen. Tällöin hominidinaaraat saattoivat huolehtia useammista jälkeläisistä samanaikaisesti, joten useammin toistuvat synnytykset kävivät mahdollisiksi.

Toinen ihmisen kulttuurikehitykselle välttämätön tekijä, pystykäynti ja eturaajojen muuttuminen liikunnan välineistä monipuolisiksi tarttumiselimiksi oli siis nimenomaan suvunjatkamisen ja jälkeläisistä huolehtimisen tarpeista syntynyt evoluutiotapahtuma, joten meidän on todettava virheelliseksi se vanha ja jatkuvasti sitkeästi elävä käsitys, että pystykäynti, aivojen kasvu ja työkalujen käyttö ovat kehittyneet yhdessä ja samantahtisesti. Tosiasiassa ihminen oli kävellyt pystyssä ainakin miljoona vuonna ennenkuin se vähitellen kypsyi työvälineitten käyttöön. Työ ja työvälineet tulivat mahdollisiksi vasta sitten kun ihmisen sosiaalinen käyttäytyminen oli muuttunut perusteellisesti. Tämä muutos oli pitkällinen ja moniaineksinen prosessi, jossa biologiset ja sosiaaliset tekijät olivat hyvin läheisesti toisiinsa liittyneet ja jonka kuluessa ihminen muuttui aggressiivisesta laumaeläimestä yhteistyökykyiseksi sosiaaliseksi eläimeksi. Keskeistä ihmisen sosiaalistumiskehityksessä oli edelleen suvunjatkaminen ja jälkeläisistä huo- lehtimisen tarve, sillä hominidien ja ensimmäisten ihmisten jälkeläiset tarvitsivat nyt niin pitkän ajan kehittyäkseen fyysisesti ja henkisesti täysi-ikäisiksi, että koko yhteisön oli osallistuttava lasten elättämiseen ja kasvattamiseen ja luomaan kaikille yhteisön jäsenille varmuus ruuan saannissa. Ihmisen oli opittava jakamaan saaliinsa ja kokemuksensa selviytyäkseen yksilöinä, laumana ja lajina. Tässä oli ihmisen sosiaalisen elämän perusehto, joka siirsi sen biologisesta evoluutiosta kulttuurievoluutioon, ja mitä pitemmälle ihmisen sosiaalistumisprosessi meni, sitä tärkeämmiksi tulivat ihmisen erilaiset yhteistoiminnalliset muodot ja sitä vähäisemmäksi kävi luonnonvalinnan osuus ihmisyhteisössä. Tätä tosiasiaa ei ymmärtänyt edes Charles Darwin, joka väitti, ettei ihmisen ja apinan välillä ole mitään oleellista eroa. Tosiasiassa lajinvalinnan prosessissa apinoiden hyvinkin voimakas lajin sisäinen taistelu ja kilpailu oli korvautunut lajinvalinnan ja ihmiseksti tulemisen prosessissa saaliin jakamisella ja yhteistoiminnalla, ja paradoksaalista kyllä, Darwinin omana aikana vallinnut tiukka Euroopan yhteisöjen sisäinen kapitalistinen kilpailu esti häntä näkemästä apinan ja ihmisen välistä oleellista eroa, lajinsisäisen taistelun häviämistä.

\section{Työ ihmisen suunnitelmallisena toimintana}

Vaikka ihmisyhteisöt siis vapautuivat lajin sisäisestä kamppailusta ja luonnonvalinnasta, ne eivät suinkaan vapautuneet riippuvuudestaan luontoon. Luonnonriippuvuus säilyi, mutta kädellinen, yhteistoiminnallinen ja puhekommunikaation oppinut ihminen kykeni muita eläimiä paremmin hankkimaan toimeentulonsa luonnosta. Muista eläimistä poiketen se siirtyi luontosuhteessaan passiivisesta sopeutumisesta aktiiviseen vaikuttamiseen, luonnon muuttamiseen.

Keskeinen tekijä tässä muutosprosessissa oli työ, jonka dynaamisena perusehtona juuri on ihmiselle lajityypillinen evoluutiossa kehittynyt yhteistoiminnallisuus. Työ voidaan määritellä ihmisen suunnitelmalliseksi vaikuttamiseksi luontoon hänen olemassaololleen välttämättömien ainesten saamiseksi sieltä. Työ suunnitelmallisena ja luovana toimintana on vain ihmiselle luonteenomainen: "Hämähäkki suorittaa tehtäviä, jotka muistuttavat kutojan työtä, ja mehiläinen saattaa vahakennojensa rakenteilla monta ihmisiin kuuluvaa rakennusmestaria häpeään. Mutta huonoimmankin rakennusmestarin erottaa parhaimmastakin mehiläisestä jo aivan alussa se, että hän on rakentanut kennot päässään ennen kuin hän ne 
rakentaa vahasta.' (Pääoma, 1. osa, s. 168169). Juuri tätä työn tuloksen rakentamista etukäteen päässä voidaan sanoa suunnitelmallisuudeksi, joka edellyttää, paitsi luovaa ajattelua, myös suunnitelman toteuttamisessa tarvittavia tietoja ja taitoja, jotka ovat aina yhteisön yhteistä työn ja ajan funktiona syntynyttä omaisuutta, traditiota. Traditio on lyhyesti ja yksinkertaistaen määriteltävissä työhön ja sosiaaliseen toimintaan liittyvän kokemuksen siirtymistä sukupolvelta toiselle. Se on samalla tavalla luonnonsyntyistä kuin ihmisten yhteisön sisäinen solidaarisuus ja yhteistoiminnallisuus, sillä se on ihmisen yhteistoiminnallisuuden seuraus ja kääntöpuoli.

\section{Traditio primitiivisissä yhteisöissä}

Primitiivisessä, eriytymättömässä yhteiskunnassa myös traditio oli varsin yksinkertaista ja eriytymätöntä ja yhteisössä tarvittavat sosiaalisen käyttäytymisen ja työnteon mallit opittiin olemalla yksinkertaisesti mukana yhteisön toiminnoissa, jolssa elannon hankkiminen ja magia olivat läheisesti toisiinsa liittyneitä. Primitiivisen yhteisön työnjako oli kehittymätöntä, kaikki tekıvät kaikkea tarpeellista ja kaikki saattoivat oppia kaiken tarpeellisen olemalla mukana sosiaalisissa ja tuotannollisissa prosesseissa.

Kun yhteisön alkuperäiset tarpeet oli tyydytetty ja kun sen hallussa oleva tekninen kokemus ja tuotantovoima olivat lisääntyneet, lisääntyivät myös yhteisön tarpeet. Tämä johti väistämättömästi sekä yhteisön sisäiseen työnjakoon että lopulta myös alkuperäisen yhteisön jakaantumiseen erillisiin, työnsä tuotteita keskenään vaihtaviin klaaneihin, joita lisäksi yhdisti elävänä säilynyt tietoisuus yhteisestä alkuperästä, yhteisistä esi-isistä. Tämä jakaantuminen oli yhteiskunnallista työnjakoa, joka väistämättömästi merkitsi myös työhön ja tuotantoon liittyvän tradition jakaantumista samassa tahdissa yhteisön elämän monimuotoutumisen kanssa. Tämä näkyi myös ideologioitten ja uskonnon muutoksessa: Maanviljelyskulttuurien kehittyessä varhaisempien kausien totemistiset, yksittäisiin kasveihin ja eläimiin kohdistuneet maagiset riitit syrjäytyivät ihmishahmoisten maan ja taivaan jumalien sekä käsityötä ja kauppaa suojelevien jumalien tieltä. Yhteiskunnallisen työnjaon kehityksen tarkastelu ei mahdu tähän esitykseen, tyydyttäköön tässä yhteydessä vain toteamiseen, että työnjako ja tekninen tietotaito siirtyi ja organisoitui varhaisessa vaiheessa aina sukujärjestelmän rakenteissa. Esimerkiksi arkaaisessa Kreikassa eri tuotannon ja sosiaalisten palvelusten alueet olivat kukin yhden klaanin hoidossa. Tuotteet vaihdettiin yhteisellä markkinapaikalla, agoralla, jossa ryhdyttiin hoitamaan myös yhteisiä hallintoasioita.

\section{Kaupunkivaltio taloudellis-sosiaalisena instituutiona}

Kreikkalaisten ja roomalaisten vanhaan sukulaitokseen nivoutunut tekninen traditio ja ammattiorganisaatio särkyi pahasti antiikin kaupunkivaltion synty- ja laajenemisprosessissa, joka alkoi 8. esikristillisellä vuosisadalla. Heettiläisvaltakunnan hajoamisen jälkeen yleiseen käyttöön tullut rauta sysäsi kreikkalaiset yhteiskunnat nopeaan taloudelliseen ja sosiaaliseen liikkeeseen, jonka lopputuloksena oli kreikkalainen kaupunkivaltio, historian ensimmäinen yhteiskuntamuodostuma, joka oli tietoisesti irtaantunut perinnäisestä heimojärjestelmästä. Muutoksen keskiössä olivat miltei maaorjien asemaan joutuneet talonpojat ja käsityöläiset, jotka yhdessä merikauppaa harjoittavien kauppiaitten kanssa ryhtyivät poliittiseen taisteluun erioikeuksiaan väärinkäyttävää heimoaatelistoa vastaan. Pitkällisen ja väkivaltaisia muotoja saaneen kamppailun jälkeen kreikkalaiset talonpojat ja käsityöläiset vapautuivat rappeutuneeseen heimojärjestelmään syntyneistä alistus- ja riistosuhteista. He muuttuivat yläluokan käytössä ja hallinnassa olleesta työvoimasta itseään hallitsevaksi pienomistajaluokaksi, joka nyt vuorostaan itse tarvitsi työvoimaa, koska valtion hallinto, sotapalvelus ja osallistuminen kansalaisyhteisön sosiaaliseen ja kulttuurielämään vei varsin suuren osan heidän ajastaan. Demokratiakehityksen synnyttämä työvoiman kysyntä täytettiin työvoiman pakkosiirroilla, orjatyövoimalla, jota saatiin varsin helposti siirtokuntakaupan välityksellä.

Heimojärjestelmän häviäminen ja orjatyövoiman intensiivinen käyttö muuttivat perusteellisesti työorganisaatiota ja ammattitraditioita Kreikassa: Käsityöläiset olivat nyt vain pieneltä osalta kaupunkivaltion syntyperäisiä jäseniä, jotka olivat oppineet ammatin perheja sukuyhteisössä. Suurin osa tuotannollisesta työstä tuli nyt muualta tuotujen orjien tehtäväksi; Heidät oli monesti koulutettava eri alojen tekniseen osaamiseen, eikä meillä ole syytä olettaa, että koulutuksessa olisi välttämättä pyritty vanhan työtradition säilyttämiseen. Se olisi ollut varsin epätarkoituksenmukaista, sillä kreikkalaisen kaupunkivaltion synty oli suurelta osaltaan johtunut heimojärjestelmän rajat ylittävistä taloudellisista ja sosiaalisista tarpeista, joista laajan merikaupan tarpeet olivat 
varsin merkittäviä. Näitä tarpeita tyydyttävä tuotanto ei siis voinut hyvin tiukasti pysytellä vanhoissa traditioissa.

Kreikkalainen kaupunkivaltio, polis, oli suunnilleen vuodesta 500 alkaen antiikin maailman taloudellinen ja sosiaalinen perusyksikkö, aluksi kreikkalaisessa oikumeneessa ja 200-luvulla eaa. alkaneitten roomalaisvalloitusten seurauksena vähitellen koko Välimeren piirissä Galliaa ja eteläistä Germaniaa myöten. Kaupunki-instituutiota tarvittiin antiikin kaudella nimenomaisesti taloudellis-sosiaalisena instituutiona, sillä sen avulla kyettiin hallitsemaan ja sääntelemään antiikin yhteiskunnan varsin polaarista rakennetta: Toisaalta olivat kaikkia oikeuksia vailla olevat orjat ja muukalaiset, joiden valvominen ja kurissapito oli kaupunkihallinnon oleellinen vastuualue. Tähän liittyen ja tätä täydentäen kaupunkiyhteisön oli tuettava myös erioikeutettujen kansalaisten taloudellista asemaa ja sosiaalista statusta, jotta he eivät köyhtyisi eivätkä liittoutuisi oikeudettomien väestöryhmien kanssa järjestelmän muuttamiseksi. Yhteiskunnallisten oikeuksien ja vaurauden tiukka polarisoituminen johti antiikin yhteiskunnassa väistämättömästi myös tuotannon ja siihen liittyvän tietotaidon joutumiseen erilleen. Sosiaalisesti ja tuotannollisesti eriytymättömässä heimoyhteiskunnassa myös tuotanto ja yhteiskunnan käytössä oleva tieto olivat toisiinsa integroituneita: Kaikki tuotannollinen kokemus ja tieto olivat periaatteessa kaikkien tuottajien ulottuvilla ja tuottajat olivat kiinnostuneita tuotantoon liittyvän tradition kartuttamisesta, koska he saivat osuutensa lisääntyneestä tuotannosta. Kreikan kaupunkijärjestelmän kehitykseen liittyvä oleellinen piirre oli tiedon etsimisen irtautuminen mytologiasta sekä luontoa ja yhteiskuntaa koskevan sekuläärisen, tieteellisen tiedon nopea lisääntyminen, mutta tämä ei enää tapahtunut tuotannon ja tuottajien ehdoilla, vaan tuotannosta irtaantuneen yläluokan ehdoilla, jolloin uutta tietoa etsittiin vain sen itsensä vuoksi ja käytettiīh ensisijaisesti vain filosofisiin spekulaatioihin, luontoa koskevąn tiedon soveltamista tuotantotekniikan kehittämiseen ei juuri yritetty. Tässä yksi syy siihen että noin 800 vuoden mittaisen kreikkalais-roomalaisen antiikin aikana pysyttiin suunnilleen sillä tuotantotekniikan tasolla, joka oli saavutettu myöhäisellä kivikaudella ja pronssikaudella. Rauta-ajan merkittävin tekniikan saavutus oli rautatyökalujen ja rauta-aseiden kehittäminen, ja niiden mahdollistaman yhteiskuntamuodostuman luominen. Tarvittiin pitkä historiallinen kehitys ja aivan uudenlainen yhteiskuntamuodostuma ennen kuin tuotanto ja yhteiskunnallinen tieto, kaksi erilleen joutunutta traditiota olivat saatettavissa yhteen.

\section{Käsityöläistraditiosta tieteelliseen traditioon}

Antiikin yhteiskunnan hajaantumisprosessi oli alkanut suhteellisen varhain, mahdollisesti jo toisella kristillisellä vuosisadalla, mutta se johti Rooman valtakunnan hajoamiseen ja valtakunnan läntisen osan häviämiseen vastaa 400-luvulla. Kansainvaellusten kaudella kehityksensä alkuun päässyt uusi yhteiskuntamuodostuma, feodaalinen yhteiskunta oli roomalaisten rakenteiden ja germaanisten heimoainesten synteesi, joka sai valmiin muotonsa 1000- ja 1100-lukujen vaihteessa. Suurin muutos antiikin yhteiskuntamuodostumaan verrattuna oli se, että keskiajan yhteiskunnan taloudellinen ja sosiaalinen perusyksikkö, kartano ei kehittynyt vapaille jäsenilleen samanlaiseksi sosiaaliseksi tukijärjestelmäksi kuin antiikin yhteiskunnan perusyksikkö, kaupunkiyhteisö. Tästä johtui väistämättömästi se, että ne jotka keskiajalla irroittautuivat maanviljelyksestä ja riippuvuudesta kartanoon, joutuivat samalla tavallaan yhteiskunnan ulkopuolelle, sillä heidän yhteytensä elannon saantiin katkesivat, eikä kirkon armeliaisuuslaitoksia lukuunottamatta ollut olemassa mitään instituutiota, joka olisi huolehtinut heidän toimeentulostaan. Kun maaorjatalonpoika karkasi käsityöläiseksi kaupunkiin, hänen oli vaihdettava kättensä työn tuotteilla elintarvikkeensa ja raaka-aineensa. Se oli hänen ainoa mahdollisuutensa ja kun hänen henkiinjäämisensä oli tuotteiden vaihdosta riippuvainen, hänen oli kehitettävä työvälineitään ja työmenetelmiään, mutta hänen ei ollut tehtävä sitä yksinään ja pelkästään oman kokemuksensa ja omien tietojensa perusteella. Keskiajan käsityöläisellä oli jälleen tukenaan traditio, joka ennen pitkää sisälsi tekniikan ja hänen tuotannollisen toimintansa kannalta keskeisen yhteiskunnallisen tiedon. Ammattikuntalaitoksesta tuli välttämätön tekijä tekniikan ja yhteiskunnallisen tradition yhdistäjänä.

Tuotannon ja yhteiskunnallisen tiedon integraatiokehitys oli aluksi varsin vaatimatonta. Tiedon ja edistyksellisen tuotannon johtoasema oli kauan katolisen kirkon yhteyteen syntyneellä luostarilaitoksella, joka siirsi ja kehitti antiikin maanviljelyksessä ja käsityössä syntynyttä traditiota. Kaupunkien käsityöläisten oli ollut perustettava sosiaalisen ja poliittisen olemassaolonsa turvaksi ja keskinäisen yhteistyönsä vahvistukseksi ammattikuntia, jotka useimmiten olivat maaseudulta kaupunkeihin siirrettyjä tuotannollisia ja sosiaalisia heimoinstituutioita, joiden mukana siis siirtyi germaanien teknistä ja sosiaalista traditiota. Itsenäisyydestään taistelevien käsityöläisammatti- 
kuntien haltuun joutunut germaaninen traditio ei hävinnyt niinkuin oli käynyt vanhan ajan heimoinstituutioille ja traditiolle antiikin kaupunkijärjestelmän syntyessä, eikä tuotantotekniikan ja uuden tiedon välille syntynyt ylitsepääsemätöntä sosiaalista muuria niinkuin antiikissa. Taloudellisesta ja poliittisesta riippumattomuudestaan taistelevat käsityöläiset omaksuivat halukkaasti uutta tietoa ja taitoa ja kehittivät sitä eteenpäin isältä pojalle, mestarilta oppipojalle niin tehokkaasti, että työn organisaation ja tuotannollisen tiedon tarpeet ylittivät monin paikoin Euroopassa ammattikuntalaitoksen rajat. Tämä heijasti vuosisataisen dynaamisen käsityöläistradition aseman heikkenemistä, mutta se ei kuitenkaan merkinnyt sen häviämistä vaan siirtymistä korkeammalle tiedolliselle ja tuotannolliselle tasolle. Porvariston luoma tuotantojärjestelmä ja porvariston luoma tieteellinen tietojärjestelmä sulautuivat yhteen kapitalistiseksi järjestelmäksi, mikä johti tuotantovoimien jatkuvasti nopeutuvaan kasvuun 1700-luvulta alkaen. Niin sanotun teollisen vallankumouksen alkuvaiheessa näkyvimmät tuotannon kehittelijät olivat vielä perinnäisessä oppipoika-järjestelmässä kouliintuneita käsityöläisiä ja kauppiaita, mutta runsaat sata vuotta myöhemmin varsin monet teollisuuden ja kaupan johtohenkilöt olivat jo saaneet uudentyyppisen systemaattisen ja tieteellisen koulutuksen teknisissä opseuraavassa kuviossa. tio oli syrjäytynyt tieteellisen tradition tieltä. Tieteellisellä tiedolla on tänään keskeinen ja erottamaton osa tekniikassa, mutta se ei kuitenkaan merkitse sitä, että tieto ja tiede olisi kohonnut kolmanneksi tuotannon tekijäksi työn ja pääoman rinnalle, tieto ja kokemus on aina ollut erottamaton osa työtä ja tekniikkaa.

\section{Lähteet}

Anderson, Perry, Passages from Antiquity to Feodalism, London NLB 1974

Finley, M., Technical Innovation and Progress in the Ancient Word, Economic History Review XVIII, N:o 1 1955, s. 29-45.

Huttunen, Pertti, Teollisen kapitalismin historialliset juuret ja massatuotannon teknisten ehtojen toteutuminen 1800-luvulla, Tekniikka, tiede ja yhteiskunta, Suomen Akatemian julkaisuja 7/1986.

Johanson, Donald, Lucy.: the beginnings of humankind, London 1981

Landes, David S., The Unbound Prometheus, Technological Change and Industrial Development in Western Europe from 1750 to the Present, London 1968

Marx, Karl, Pääoma. Kansantaloustieteen arvostelua, 1. osa, Moskova 1974

Pugliarello, Georg-Doner, Dean B. (ed), The History and Philosophy of History, Urbana 1979

Schtajerman, E.M., Die Krise der Sklavenhalterordnung im Westen des römischen Reiches, Berlin 1964.

Thomson, Georg, Aescylus and Athens, A Study in the Social Origin of Drama, New York 1972 


\section{AIKUISKASVATUS}

\section{The Finnish Journal of Adult Education \\ Vol. 7, 4/1987 \\ ISSN 0358-6197}

Summary

Huttunen, Pertti 1987. Technology and Tradition. Observations on Developments in the Adoption of the Production System.

Bipedalism, typical of man, in primarily connected with the needs of tending the offspring. It seems that work and the use of tools became possible only as a consequence of approximately a million years of socialization development entailing bipedalims. Developments in socialization were accompanied by the increasing importance of the various forms of social behaviour which were gradually adopted. In later stages of this process of change work assumed a central role. In primitive communities hardly any division of labour existed. But with increasing production experience the productive capacity and the needs of the labour force lead to an internal division of labour in communities. Later on, this development lead to the beginning of the clan system, within which a formerly coherent tradition connected to work and production was split and distributed between various clans. The birth of the urban society in the Ancient World on the other hand was the end of this organization of craft, tradition and work based on kin. In the Antiquity the slave system encouraged the separation of the growing knowledge of nature and society from the technical tradition, whereas, as a consequence of historical and social development, the artisans of Medieval towns had at their disposal social and productional organizations, guilds, within which technical tradition and a wider knowledge base became integrated. And, in time, growth in the forces of production, resulting from an increasing need for exchange, surpassed the boundaries of the quild organization. The artisan tradition was then transformed into an educational tradition with a scientific base. 